\title{
Prelimanary Investigation on The Factors That Influencing The Maintenance Cost of Apartment
}

\author{
Nor Aini Salleh ${ }^{1, a}$, Mohd Khairul Annuar Mohd Yakin ${ }^{1}$, Kharizam Ismail ${ }^{2}$ and Yuhainis Talib² \\ ${ }^{1}$ Department Of Estate Management, Faculty Of Architecture, Planning \& Surveying, Universiti Teknologi MARA Cawangan Perak, Seri \\ Iskandar Campus, 32610 Seri Iskandar, Perak, Malaysia \\ ${ }^{2}$ Department Of Quantity Surveying, Faculty Of Architecture, Planning \& Surveying, Universiti Teknologi MARA Cawangan Perak, Seri \\ Iskandar Campus, 32610 Seri Iskandar, Perak, Malaysia
}

\begin{abstract}
Housing is a basic need for all. The increasing numbers of population and income had increase in housing demand. Thus, it has led to the construction of apartments to meet the needs of people and to reduce the use of land to build residential buildings. From year to year, maintenance costs of the building are increased. To ensure the maintenance cost for apartment residence maintenance can be reduced, it is important to determine the factor that influence the maintenance cost of the apartment. This paper is to investigate and identify the factors contributing the increase of maintenance costs. The first objective of this study is to determine the factors that affect the cost of maintaining the apartment and meanwhile the second objective is to rank the factors that influence the maintenance cost of the apartment at Johor Baharu Tengah. To achieve the objectives of the study, the questionnaires were distributed to the parties involved in the management of building. Results of this study concluded that there are five factors that influence maintenance cost are the expectations of tenants, building age, building material, failure to execute maintenance at the right time and budget constraints.
\end{abstract}

Keywords: Maintenance Costs Factors, High rise buildings, Building Owners, Tenants and Types of Maintenance

\section{Introduction}

The increase in demand for housing and the lack of land for the construction of landed residential properties in major urban areas in Malaysia such as Penang, Kuala Lumpur, Selangor and Johor Bahru, has led to the rapid development of high-rise residential schemes in highdensity areas. Every apartment requires building maintenance to ensure the building in good condition. Building upkeep is the blend of specialized and managerial activities to guarantee the things and components of a building in a worthy standard to perform its required functions. So as to execute building upkeep assignments productively, a legitimate building support plan and observing framework is vital. According to [14], building support administration is an operation including the connection or mix of specialized, social, legitimate and financial determinants that oversee and deal with the utilization of structures. It can be contended that numerous individuals don't comprehend the significance or hugeness of building upkeep and its administration, specifically the acknowledgment that the productivity of a building upkeep framework adds to the pay of the organization's owning or leasing the building [13]. High building maintenance involves many aspects. An important aspect of building maintenance is of the

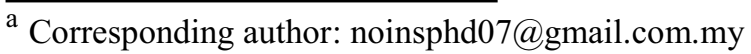


maintenance costs. Maintenance costs correctly and efficiently will ensure that a building can be managed properly.

\section{FACTOR THAT INFLUENCES THE MAINTENANCE COST OF APARTMENT}

Buildings must be properly maintained by a person who has the skills to maintain. Definition of maintenance has many interpretations. BS 3811(4) stated that maintenance is "any work done to maintain or restore each facility", an example every part of a site, building and every each which related with building must be at acceptable standard. Besides that, maintenance is a work that must be done to restore and maintain a building of damage according to a present standard. Hence, building maintenance is to keep a building in good condition and condition appropriate to its use [9, 42]. Maintenance of building is a combination involving technical and administrative measures to ensure the item and all elements related to the building in which the desired standard conditions acceptable to perform the desired function [14]. Therefore, the ultimate aims of maintaining the building according to [4] are to maintain the value of the investment, to ensure buildings in an acceptable condition and the required standard, to present a good appearance of the building, and to conserve the values of history and architecture of the building.

There are various types of building maintenance as mentioned by [12], building maintenance can be divided into three such as reactive (day- to- day repair); preventive maintenance which include cyclic and condition based maintenance, and modernisation and improvement which include additional works which need as a result of new legislation and regulations. In other words there are two major categories of building maintenance namely planned maintenance and unplanned maintenance [26]. Maintenance cost is covering overall cost or budget set to take care of the building condition. Maintenance cost also related to direct cost like material, labour, plant and tool that use to maintain the building. Meanwhile indirect cost like management cost and administrative staff and cost overhead is also maintenance cost of high rise buildings. [40] mentioned that maintenance and operation expenditure is one of the major housing cost components. Usually, maintenance and operation of building contribute expenses one-third to half from total cost of maintenance work depend on a type of residential such as condominium, apartment, flat and other. There are several factors that influence the maintenance cost of a high residential building. Generally, they can be divided into five groups such as building characteristics, tenant factors, maintenance factors, new regulation factors and other factors.

\subsection{Building characteristics factor}

Building characteristic is one of the factor that influence on the maintenance. Building characteristic are related to building age, function, building area, height of building, types of structure, finishes services of building, construction material and other. Every building has specific characteristics and differences in the distribution of the total cost of prescribed maintenance to ensure the building is always in a good condition [46]. [34,45 \& 44] also noted that maintenance cost will increase due to the increasing age of the building.

Based on [43], all building will pass aging in various exposure conditions. Building height and building area also a factor that affects the maintenance cost [44]. Part of building maintenance work does involve building services. The building services system should be made and implement to provide a healthy and safe life to the residents or occupant of the building [19] [5] in his opinion mentioned that the building services need to be implemented for every building, including ventilation, lighting, power supply, water supply, sanitation, communication, transportation and another system. Building services and structure of building become elements that also affect maintenance cost. In this phenomenon, a lot of financial resources need to be allocated for inspection, maintenance, repair, rehabilitation and replacement of building structure [32]. [5] also agreed that, to maintain the structural stability of the building, inspection and maintenance should be carried out from time to time to ensure the safety of occupant in a safe condition. Maintenance and asset cost operation and services life influenced by the choice of material selected. To repair and replace building component that had broken down will affect the choices of material used. Better quality materials do require high maintenance cost [43].

\subsection{Tenant Factor}

Tenant or occupier at high residential building influence the maintenance cost of housing. According to [35], the maintenance requirement caused by tenant as much as 25 percent. Thus, strategies that can be done by the landlord in closing the gap between expensive maintenance and management of legitimate expectations or the demand of customers with tenant and resident participation in housing management [53]. Expectation of tenants or residents, use of property, vandalism by the occupier or a tenants, delay and failure in report problems and accessibility to the property give effect to maintenance $\operatorname{cost}[12,36,6 \& 5]$.

\subsection{Maintenance Factor}

Based on [12], maintenance factor may have a big influence on housing maintenance cost. Generally, maintenance factors can be divided into two main factors namely technical factor and administrative factor. From the aspect of technical factor, several aspects that affect maintenance cost are poor workmanship and poor quality of the spare part and material. In the aspect of administrative factor, aspect which influences maintenance cost are poor maintenance management, budget constraint, failure to execute maintenance at right time and poor budgetary control $[29,17,18,27,31,21$, $37,2,24]$. 


\subsection{Regulation Factor}

[12] in their study, proved that changes in regulations clearly affect maintenance cost of housing. Maintenance activity is highly sensitive to changes in the local and national regulation. Statutory legislation regulates many activities of those who are involved in built environment industry. Building control legislation set up minimum standards that buildings are safe and efficient to use [5]. Safety legislation is to eliminate accidents in the building [24]. This legislation control and restrict how maintenance activity is carried out and of cause does affect cost of maintenance.

\subsection{Other Factor}

Third party vandalism is a serious problem that occurs in some high rise residential building [49]. The damage by the third party will require additional maintenance cost for repairing the damage that has been done. Another factor that leads to housing maintenance cost increase is due to poor or lack training for staff maintenance. According to [31], of the reasons for poor operating practices in the management of maintenance is due to lack of maintenance staff training. Staff maintenance or skilled operator are the factor that affect the performance of maintenance [37].

\section{Study Area and Methodology}

District of Johor Bahru Tengah was taken as a case study. It is one of the ten districts that make up the state of Johor. The study area covers an area of 338.5 square kilometers which includes Skudai, Nusajaya, Ulu Tiram, Masai, Kangkar Pulai, Gelang Patah, Plentong, and Lima Kedai. This district are also known as metropolitan Johor Bahru because of the number of population in the district exceed 600,000 people and now the number of population is increasing to 525,351 people [39]. In this area there are about one hundred and twenty two (122) apartment units, however the focus is only on medium cost apartment and high cost apartment that has been built between year of 1990 to 2014. Therefore the total number of sample in this research is Seventy Six (76) units of building apartment. This study used quantitative method (Likert Scale) to gather data from respondents in selected apartment at Johor Bharu (1990 - 2014). Five point scale ranging from "not impacting at all" on one end to "impacting a great deal" on the other with "to some degree" in the middle. In the survey form, five main variables of maintenance factors were asked to the respondents. They are, building characteristic factors, tenant factor, maintenance factor, regulation factor and other factors such as vandalism and lacking of staff training. Questionnaire survey had been distributed to all building manager or building supervisor or maintenance management officer or accountant who can provide valuable information related to building maintenance cost, this is because of the small population (less than 100). A total of 76 questionnaires survey form had been distributed directly to respondents. It is believed that to sample the whole populations can achieve a desirable level of precision [15]. All the data from the questionnaire survey had been statistically analysed with SPSS software. Two types of analysis were used, namely descriptive mean and ranking. First analysis was to derive the mean score of every variable. Second analysis was to rank the variables according to the most influence factor affected maintenance cost in the buildings.

\section{Results and discussions}

Out of 76 questionnaires survey form that has been distributed only 35 respondents (46\%) participated in the survey. Although the response rate in this study was low, it was considered acceptable because it was sufficient for the population less than 1000 respondents[33]. [16] mentioned the research is only need 30 per cent response rate to produce results that can be believed and trusted in order to achieve the objectives of the study. The first objective of this study was achieved based on desk study analysis. The researcher found that there were twenty (20) variable factors that influence maintenance cost of apartment. The twenty (20) variables then grouped into five main factors such as building characteristics, tenants' factor, maintenance factor, legislation factor and other factors. Building characteristic has five variable factors that influence maintenance cost of the apartment that are building age, building height and building area or size, building services, type of structure and building material. The second factors are tenants' factor. Tenant factor has five variables factor that influence maintenance cost of high-rise building such as high expectation of tenants, use of the building, vandalism by the tenants, delay in reporting failures and accessibility to the property. Maintenance factor was divided into two main factor which are technical factor and administration factor. Technical factor has two variables such as poor workmanship and poor quality of spare part and materials. Administration factor also has five variables factor that influences maintenance cost of apartment that are poor maintenance management, budget constraints, poor failure reporting procedures, failure to execute maintenance at the right time and poor budgetary control. Second last was legislation factor. Lastly, two variables in other factors are third party vandalism and poor or lack of staff training. Based on the factors as mentioned before, it can be concluded that there are many factor that influence the maintenance cost of apartment. Factor that influence the maintenance cost of an apartment is summarised in Table 1 below.

Table 2 shown that the highest mean score of the most influence factor and the lowest mean score will represent the least influence factor. The first rank of influences factor is a high expectation of tenant factor with a mean score of 4.06. The next ranking is building age, followed by building material. The lowest rank is new regulations factor with a mean score of 2.60. In table 2 , the expectation of tenant has proven to possess the highest rank at the top of the list. This gives the impression that the expectations of tenants have made the 
most impact on the maintenance cost of high rise building. The factors that influence tenant demand due to thing such as increasing tenant demand toward better lifestyle and living environment. Thus, has led to an increase in maintenance requirements and maintenance costs. Other than that, it may also caused by the maintenance activities that was not in the contract between the tenant and the local authorities (owner). Building age is the second rank of the factors that influence maintenance cost of high rise buildings. Building age is a critical source of high maintenance cost of the building. The longer the age of the building, the higher the maintenance cost. According to [22] explains that in making provision for maintenance budgets, one of the key elements that need to be measured is the age of the building. This is due more the maintenance work needs to be carried out for older buildings. Building materials are ranked third factor that influence maintenance cost of high rise building. Rising material cost will cause increased maintenance cost, especially when there is defect in a building. The selection of building material by the management which is not suitable also gives influence to the increasing of the maintenance cost. Failure to execute maintenance at the right time was the fourth-ranked factor that influence maintenance cost of high rise building. This finding is similar to the work of [31], he stated that the failure or delay to perform maintenance tasks at the right time can cause maintenance expenses. Budget constraint was fifth rank for the factor that influence maintenance cost of high rise building. Maintenance budget are often based on financial priorities laid down by the management.

Table 1: Factors that influence the maintenance cost of apartment

\begin{tabular}{|c|c|c|}
\hline $\begin{array}{c}\text { MAIN } \\
\text { GROUPS }\end{array}$ & VARIABLES & AUTHORS \\
\hline $\begin{array}{l}\text { Building } \\
\text { Characteristic }\end{array}$ & $\begin{array}{l}\text { Building age, } \\
\text { Building height } \\
\text { and building area } \\
\text { or size, Building } \\
\text { services, Types of } \\
\text { structure, Building } \\
\text { Material. }\end{array}$ & $\begin{array}{l}\text { Azlan, 2010; } \\
\text { Sonthya, 2006; John } \\
\text { and Croome, 2005; } \\
\text { Neves, Frangopal, \& } \\
\text { Cruz, 2004; Shabha, } \\
\text { 2003; Skinner, 1982; } \\
\text { O'Neil, 1974; and } \\
\text { Slater, 1892 }\end{array}$ \\
\hline $\begin{array}{l}\text { Tenant } \\
\text { Factors }\end{array}$ & $\begin{array}{l}\text { High expectation } \\
\text { of tenant, } \\
\text { Improper use of } \\
\text { the building, } \\
\text { Vandalism by } \\
\text { tenant, Delay in } \\
\text { reporting failures, } \\
\text { Accessibility to } \\
\text { the property. }\end{array}$ & $\begin{array}{l}\text { Bavani, } 2010 ; \\
\text { Azlan, 2010; El- } \\
\text { Haram \& Horner, } \\
2002 ; \text { Olubudon, } \\
\text { 2001; Yip, 2001; } \\
\text { and Olubodun \& } \\
\text { Mole,1999 }\end{array}$ \\
\hline $\begin{array}{l}\text { Maintenance } \\
\text { Factor }\end{array}$ & $\begin{array}{l}\text { Technical factor: } \\
\text { Poor } \\
\text { workmanship, } \\
\text { Poor quality of } \\
\text { spare part and } \\
\text { materials. } \\
\text { Administration } \\
\text { factors: Poor } \\
\text { maintenance } \\
\text { management, } \\
\text { Budget } \\
\text { constraints, Poor } \\
\text { failure reporting } \\
\text { procedures, } \\
\text { Failures to execute } \\
\text { maintenance at the } \\
\text { right time, Poor } \\
\text { budgetary control. }\end{array}$ & $\begin{array}{lr}\text { El-Haram } & \text { and } \\
\text { Horner, 2002; Mills, } \\
\text { 1980; Hammad, Al- } \\
\text { Mubaiyadh and } \\
\text { Mahmoud, 1996; } \\
\text { Horner et al., 1997; } \\
\text { Love and Irani, } \\
2003 \text {; Narayan, } \\
\text { 2003; Khalid, } \\
\text { Marosszeky and } \\
\text { Davis, } \\
\text { Pascual, Meruane } \\
\text { and Rey, 2008; Ali, } \\
\text { 2009 and H. H. Y. } \\
\text { Lee \& Scott, 2009. }\end{array}$ \\
\hline $\begin{array}{l}\text { Legislation } \\
\text { Factor }\end{array}$ & $\begin{array}{l}\text { Changes in } \\
\text { regulation }\end{array}$ & $\begin{array}{l}\text { El-Haram and } \\
\text { Horner, 2002; Azlan } \\
\text { et al., 2010; and H. } \\
\text { H. Y. Lee and Scott, } \\
2009\end{array}$ \\
\hline Other Factor & $\begin{array}{lr}\text { Third party } \\
\text { vandalism and } \\
\text { lack of } \\
\text { training. }\end{array}$ & $\begin{array}{l}\text { Tiun, 2003; } \\
\text { Narayan, 2003; and } \\
\text { Pascual et al., } 2008\end{array}$ \\
\hline
\end{tabular}


Table 2. Ranking of factors influencing maintenance costs of building

\begin{tabular}{|l|c|c|}
\hline \multicolumn{1}{|c|}{ Variables } & N & Mean \\
\hline High expectation of tenant & 35 & 4.06 \\
\hline Building age & 35 & 3.46 \\
\hline Building material & 35 & 3.37 \\
\hline $\begin{array}{l}\text { Failure to execute } \\
\text { maintenance at the right } \\
\text { time }\end{array}$ & 35 & 3.29 \\
\hline Budget constraints & 35 & 3.26 \\
\hline $\begin{array}{l}\text { Improper use of the } \\
\text { property }\end{array}$ & 35 & 3.23 \\
\hline $\begin{array}{l}\text { Poor maintenance } \\
\text { management }\end{array}$ & 35 & 3.09 \\
\hline Vandalism & 35 & 3.03 \\
\hline Poor or lack of training & 35 & 3.00 \\
\hline Poor budgetary control & 35 & 2.94 \\
\hline Type of structure & 35 & 2.91 \\
\hline Third party vandalism & 35 & 2.89 \\
\hline Delay in reporting failures & 35 & 2.89 \\
\hline $\begin{array}{l}\text { Poor quality of spare part } \\
\text { and materials }\end{array}$ & 35 & 2.86 \\
\hline Building services & 35 & 2.86 \\
\hline $\begin{array}{l}\text { Building height and } \\
\text { building area or size }\end{array}$ & 35 & 2.83 \\
\hline Poor workmanship & 35 & 2.80 \\
\hline $\begin{array}{l}\text { Accessibility to the } \\
\text { property }\end{array}$ & 35 & 2.77 \\
\hline $\begin{array}{l}\text { Poor failure reporting } \\
\text { procedures }\end{array}$ & & 2.74 \\
\hline New regulations & & 2.60 \\
\hline
\end{tabular}

\section{Conclusion}

This research provides valuable information related to maintenance cost of apartment buildings. The costs of maintaining a building always become an issue to management and owner of the property. Therefore, steps should be taken or made to reduce the maintenance cost of high rise building. All parties should give cooperation in overcoming the problem of increasing maintenance cost. All parties such as tenant and residents should participate in the work of maintenance management, for example, the residents should together taking care the common area of property. In addition to this, building maintenance management should also introduce operation manual and regulations to all the residents as a guideline together with the budget of maintaining the building in order to create awareness and self-belonging to each other. By introducing the system, they should be able to comply the regulations as provided by the management. Further actions to reduce the cost of building management are the maintenance management should adopt effective maintenance management principles that are suited to their buildings. Building maintenance management has to conduct maintenance work accordingly to the schedule that has been planned. Apart from that strict enforcement should be implemented to all resident or tenant regarding maintenance fee payment from time to time. A Top leader of maintenance management department must make a right decision on selection to choose staff with qualification that is equivalent to post applied. Hence, provide a good quality work on maintenance duties up to the standard required or expected by the relevant parties' such as occupiers and building owners.

In conclusion, this research had given benefits to many related parties such as developer - the research would help the developer understand the factor affecting maintenance cost apartment. The developer will also know how to improve their services that influnce the maintenance cost of apartment and indirectly minimize the maintenance cost of their building. Hence, will save the maintenance cost when they manage the high rise building for new development. The government body will be able to identify the factor affecting maintenance cost of high-rise building and budget that need to be allocated for maintenance activity. First hand information will reduce the maintenance cost of government building, building owners and tenants - this research also gives valuable information to the building owners and tenants. The building owners and tenant will know factor why the maintenance cost different every year. Thus required them to take care of the building where they stayed.

\section{References}

1. Al-Arjani, A. H. (1995). Impact of cultural issues on the scheduling of housing maintenance in a Saudi Arabian urban project. International Journal of Project Management,, Vol. 13 No. 6, pp. 373-382.

2. Ali, A. S. (2009). Cost decision making in building maintenance practice in Malaysia. Journal of Facilities Management, 7, pp 298306.

3. Allen, D. (1993). What is Building Maintenance? Facilities, 11 iss 3, 7-12.

4. Azlan, S. A. (2009). Cost decision making in building maintenance practise in Malaysia. Journal of Facilities Management, Vol.7 No.4, pp 298-306.

5. Azlan, S. A., Kamaruzzaman, S.-N., Sulaiman, R., \& Peng, Y. C. (2010). Factors affecting housing maintenance cost in Malaysia. Journal of Facilities Management, Vol 8, pp 285-298.

6. Bavani, M. (2010). Most lifts faulty due to vandalism, The Star Malaysia, March 1,.

7. Chanter, B., \& Smallow, P. (2007). Building Maintenance Management. Blackwell Science: Oxford.

8. Cheung, M. S., \& Kyle, B. R. (1996). Service life prediction of concrete structures by reliability analysis. Construction and Building Materials, Vol. 10 No. 1, pp.45-55.

9. Chudley, R. (1981). The Maintenance and Adoptation of Building. New York: Lognan Inc.

10. David, W. W., \& Arthur, B. (1989). Management to maintain quality in buildings", Proceedings of Implementation of quality in construction. Copenhagen, .

11. Haram, M. A. (1995). Integration approach to condition-based reliability assessment and 
maintenance planning. ( $\mathrm{Ph}$ D. Thesis), University of Exeter.

12. El-Haram, M. A., \& Horner, M. W. (2002). Factor affecting housing maintenance cost. Journal of Quality in Maintenance Engineering, Vol. 8 No 2, pp. 115-123.

13. Emma, M. A. Z., Syahrul, \& N.K. (2009). Personnel characteristics of maintenance practices a case of high-rise office building in Malaysia. journal of Subtainable Development, Vol 2 No.1, 111-116.

14. Francis, W. H. Y., Lee, W.L ,Ng.C.K. (2001). Building energy efficiency and the remuneration of operation and maintenance personel. Facilities, 20, 406-413.

15. Glen, ID (1992). Determining sample size. Agricultural Education and Communication Department, Florida Cooperative Extension Service, 20 Mac 2013, available at: http://edis.ifas.ufl.edu/pd006

16. Gillham, B. (2000). Developing $a$ Questionnaire. Continuum, London.

17. Hammad, A. A.-., Al-Mubaiyadh, S., \& Mahmoud, T. (1996). Public versus private sector's assessment of problems facing the building maintenance industry in Saudi Arabia. Building Research \& Information, Vol. 24 No.4, pp. 245-254.

18. Horner, R. M., EL-Haram, M. A., \& Munns, A. (1997). Building maintenance cost strategy: a new management approach. International Journal of Quality in Maintenance, Vol. 3 No.4, pp273-280.

19. John, G. A., \& Croome, D. J. C.-. (2005). Contextual prerequisites for the application of ILS principles to the building services industr. Engineering, Construction and Architectural Management, Vol. 12 No. 4, pp. 307-328.

20. Kelly, A., \& Harris, M. J. (1978). Management of Industrial Maintenance. Butterworths, London.

21. Khalid, K., Marosszeky, M., \& Davis, S. (2006). Managing subcontractor supply chain for quality in construction. Engineering, Construction and Architectural Management, Vol. 13 No. 1, pp. 27-42.

22. Lateef, O. A. (2008). Building maintenance management in Malaysia. Journal of Building Appraisal, Vol. 4 No. 3, pp. 207-214.

23. Lee, \& Wordsworth, P. (2001). Lee's Building Maintenance Management. Blackwell science: Oxford.

24. Lee, H. H. Y., \& Scott, D. (2009). Overview of maintenance strategy, acceptable maintenance standard and resources from a building maintenance operation perspective. Journal of Building Appraisal, Vol. 4 No. 4, pp. 269-278.

25. Leonardo, L. (2011). Interview, senior maintenance engineer. In Y. C. f. M. Contacting (Ed.). Dammam.

26. Leong, K. C. (2004). The essence of good facility management-Aguide for maximization of facilities asset economic life and asset opptimissation for realiable services and user satisfaction. (Vol. Vol 24).

27. Love, P. E. D., \& Irani, Z. (2003). A project management quality cost information system for the construction industry. Information \& Management,, Vol. 40 No. 7, pp.649-661.

28. Malek, A. (2013). Simple Research.

29. Mills, E. D. (1980). Building Maintenance and Preservation-A Guide to Design and Management. Butterworths.

30. Mjema, E. A. M. (2002). An analysis of personnel capacity requirement in the maintenance depertment by using simulation method. journal of Quality in Maintenance, Vol. 8 No. 3, pp. 253-273.

31. Narayan, V. (2003). Effective Maintenance Management: Risk and Reliability Strategies for Optimizing Performance. New York, NY: Industrial Press.

32. Neves, L. C., Frangopal, D. M., \& Cruz, P. S. (2004). Cost of life extension of deteriorating structures under reliability-based maintenance. Computers \& Structures, Vol. 82 Nos 13-14, pp. 1077-1089.

33. Neuman, W.L. (1991). Social Research Methods: Qualitative and Quantitative Approaches. United States Of America: Pearson

34. O'Neil, D. (1974). The determinants of housing cost. Architects Journal, Vol. 3, pp. 753-755.

35. Olubdun, F. (2001). A multivariate approach to the prediction of maintenance needs in public housing: the tenant dimension. Structural Survey, Vol. 19 No. 2, pp. 133-141.

36. Olubodun, F., \& Mole, T. (1999). Evaluation of defect influencing factors in public housing in the UK. Structural Survey, Vol. 17 No 3, pp. 170-178.

37. Pascual, R., Meruane, V., \& Rey, P. A. (2008). On the effect of downtime costs and budget constraint on preventive and replacement policies. Reliability Engineering \& System Safety Vol. 93 No. 1, pp. 144-151.

38. Raymond, C. M., \& Joan, C. F. E. (1991). Preventive Maintenance of Buildings. London: Chapman and Hall.

39. Report Majlis Bandaya Jphor Bharu (2015)

40. Rydell, C. P. (1970). Factor Affecting Maintenance and Operating Cost in Federal Public Housing Projects. New York NY: The Rand corporation.

41. Sanjay, M. (2014). Primary Data Analysis.

42. Seeley, I. H. (1987). Building Maintenance. Palgave: New York, NY.

43. Shabha, G. (2003). A low-cost maintenance approach to high-rise flats. Facilities, Vol. 21 Nos 13/14, pp.315-322. Shohet, I. M., \& Pacuik, M. (2004). Service life prediction of exterior cladding components under standard conditions. Construction Management and Economics, Vol. 22 No. 10, pp.1081-1090. 
44. Skinner, N. P. (1982). Local authority house maintenance - the variation in expenditure. Housing Review, Vol. 31, pp. 92-94.

45. Slater, K. (1892). An investigation into hospital maintenance expenditure in the North West Regional Health Authority (P. S. (Ed.) Ed.). Bradon,London: New Directions, E. \& F.N. Spon.

46. Sonthya, V. (2006). Relationship between building characteristics and rental to support serviced apartment investment. Paper presented at the paper presented at the Pacific Rim Real Estate Society (PRRES) Conference.

47. Teo, E. A. L., \& Harikrishna, N. (2006). A quantitative method for efficient maintenance of plastered and painted facades. Construction Management and Economics, Vol. 24 No. 12, pp. 1283-1293.

48. Thompson, P. (1994). The maintenance factor in facilities management. Facilities, Vol. 12 No. 6, pp. 13-16.

49. Tiun, L. T. (2003). The Management of High Rise Housing Complex, Utusan Melayu.

50. Tiun, L. T. (2006). Managing high- rise residential building in Malaysia : Where are we? Paper presented at the 2ND NAPREC CONFERENCE, Universiti Sains Malaysia.

51. UmarAl-Turki. (2011). A framework for strategic planning in maintenance. Journal of Quality in Maintenance Engineering, 17 No 2, 150-162.

52. Wong, L. T. (2006). A cost model for plumbing and drainage systems. Facilities, Vol. 20 Nos 11/12, pp 986-993.

53. Yip, N. M. (2001). Tenant participation and the management of public housing - the estate management advisory committee of Hong Kong. Property Management, Vol. 19 No. 1, pp. 10-18.

54. Yusoff, Y. M., Tawil, N. M., N. Hamzah, Abdullah, N. A. G., \& Musa, A. R. (2011). Tinjauan Kesan Fasiliti Kediaman Bertingkat Terhadap Amaun Dana Pengurusan. Journal Design + Built, 4, 32-40.

55. A. Mecke, I. Lee, J.R. Baker jr., M.M. Banaszak Holl, B.G. Orr, Eur. Phys. J. E 14, 7 (2004)

56. M. Ben Rabha, M.F. Boujmil, M. Saadoun, B. Bessaïs, Eur. Phys. J. Appl. Phys. (to be published)

57. Luigi T.De Luca, Propulsion physics (EDP Sciences, Les Ulis, 2009)

58. F. De Lillo, F. Cecconi, G. Lacorata, A. Vulpiani, EPL, 84 (2008) 